\title{
Spanning the boundaries of work: Workplace participation, political efficacy, and political involvement
}

\author{
Guowei Jian \\ Cleveland State University, g.jian@csuohio.edu \\ Leo Wayne Jeffres \\ Cleveland State University, I.jeffres@csuohio.edu
}

Follow this and additional works at: https://engagedscholarship.csuohio.edu/clcom_facpub

Part of the Organizational Communication Commons, Politics and Social Change Commons, Social Influence and Political Communication Commons, and the Work, Economy and Organizations Commons How does access to this work benefit you? Let us know!

\section{Publisher's Statement}

This is an Author's Accepted Manuscript of an article published in Communication Studies 03-11-2008, available online: http://www.tandfonline.com/10.1080/10510970701849370

\section{Recommended Citation}

Jian, G., \& Jeffres, L. (2008). Spanning the boundaries of work: Workplace participation, political efficacy, and political involvement. Communication Studies, 59(1), 35-50. doi:10.1080/10510970701849370

This Article is brought to you for free and open access by the School of Communication at EngagedScholarship@CSU. It has been accepted for inclusion in Communication Faculty Publications by an authorized administrator of EngagedScholarship@CSU. For more information, please contact library.es@csuohio.edu. 


\section{Spanning the Boundaries of Work: Workplace Participation, Political Efficacy, and Political Involvement Guowei Jian \& Leo Jeffres}

Based on the political spillover theory, this study examines the boundary-spanning aspect of workplace participation - the association between participation at work and in politics. A telephone survey was conducted using a regional probability sample. Results indicate that decision involvement at work is positively associated with political voting while work community participation is positively associated with involvement in local communities and political party and campaign activities. The study reveals that internal political efficacy mediates the relationship between job autonomy and political participation.

Keywords: Political Efficacy; Political Participation; Political Spillover Theory; Work Community; Workplace Democracy; Workplace Participation

Workplace participation has seen increased attention in the past decades (e.g., Cheney et al., 1998; Deetz, 1992, 1995; Harrison, 1994; McLagan \& Nel, 1995; Seibold \& Shea, 2001; Stohl \& Cheney, 2001). However, organizational communication research on workplace participation has been largely confined within the organizational boundaries. In fact, workplace in general has been understudied with regard to its impact on political behavior (Mutz \& Mondak, 2006; Putnam, 2000). In spite of Cheney's (1995) call for attention to "the relationship between participation inside and

Guowei Jian (Ph.D., University of Colorado, 2003) is an Assistant Professor in the School of Communication at Cleveland State University. His research interests include organizational culture, work participation, and communication technologies at work. Leo W. Jeffres (Ph.D., University of Minnesota, 1976) is a Professor in the School of Communication at Cleveland State University. He is the author of four books, including Urban Communication Systems (Hampton Press, 2002). His research interests include media effects, neighborhoods and urban communication systems, and communication technologies. Correspondence to: Guowei Jian, School of Communication, Cleveland State University, 2121 Euclid Ave. MU 247, Cleveland, OH 44115-2214, U.S.A. Tel: 216-687-3995. E-mail: g.jian@csuohio.edu 
outside the workplace" (p. 187), scant empirical research has attended to this boundaryspanning dimension of workplace participation (Cheney et al., 1998). Grounded in the political spillover theory (Pateman, 1970), this study intends to empirically examine the association of workplace participation and political involvement.

Drawing on classical democratic theories by Mill (1910), Cole (1919), and Dahl (1956), Pateman (1970) proposes that workplace functions as a significant training ground for adult socialization and development of important political skills, and that participatory workplace practices lead to participatory democratic practices in the social political process outside workplace. Pateman suggests internal political efficacy (IPE) as the mediating factor in the association between participation at work and in politics. Since the 1970s, empirical efforts mainly by political scientists (e.g., Elden, 1981; Greenberg, 1986; Mason, 1982; Milbraith \& Goel, 1971; Peterson, 1992; Sheppard \& Herrick, 1972; R. Sobel, 1993) have focused on the direct association of workplace participation either with IPE or political participation. The mediating effect of IPE has rarely been tested (Greenberg, Grunberg, \& Daniel, 1996). One of the objectives of this study is to examine the mediating effect of IPE in the association between participation at work and in politics.

Additionally, the conceptualization of workplace participation since Pateman (1970) has mainly been about job autonomy and work decision involvement. Such an instrumental definition of workplace overlooks the social dimension of work as a community, in which socialization among employees goes beyond contractual relationships and authority structures. Tapping into the socialization at work as a community may further our understanding about the association between participation at work and in politics. In this study, we propose work community participation as an additional dimension to the traditional definition of workplace participation and explore its association with political involvement.

The findings of this study will not only contribute to the development of the political spillover theory but also offer empirical evidence to the discussion over the role of corporations in today's society. Deetz (1992) argues that today's corporations are the new public sphere, where social goods are appropriated and policy decisions made. This study holds the potential to offer empirical evidence with regard to whether microsocial work practices, such as individual job autonomy and socialization in work communities, have far reaching effects on democratic political processes outside the workplace.

The paper will first introduce the political spillover theory, discuss the limitations existing in current empirical research and propose our hypotheses. It will then report an empirical study that we conducted using telephone-survey interviews based on a regional probability sample. Finally, the paper will discuss the results, implications, and limitations of the study and offer directions for future research.

\section{The Political Spillover Theory}

Various classical democratic theorists, such as Rousseau (1968), Mill (1910), and Cole (1919), point to the educative effects of nonpolitical social institutions in 
cultivating people's participation in a democratic political system. Contemporary scholars in political science, communication, and sociology have begun to offer theories and empirical evidence to such effects. For instance, Putnam (1995, 2000) argues that nonpolitical social institutions are a critical part of the social capital- "social networks and norms of reciprocity and trustworthiness," which are fundamental to the functioning of the American democratic political system. Coleman (1990), on the other hand, provides analytical insights into the connection between social capital embedded in social networks and political voting behavior. Empirically, Cassel (1999) demonstrates the effects of voluntary associations on political involvement. A recent study by Kwak, Shah, and Holbert (2004) finds that both formal nonpolitical associations, such as religious and public attendance (e.g., public exhibits and libraries), and informal socializing strongly influence individuals' civic engagement.

Specific to the effect of the workplace as an involuntary nonpolitical institution on political engagement, two lines of research have emerged. One line of research focuses on the spillover effect of political discourse in the workplace. For instance, Mondak and Mutz (2001) and Mutz and Mondak (2006) propose that the workplace provides a social context for public dialogue and has the greatest capacity for workers to be exposed to opposing political views. Research (Huckfeldt, Beck, Dalton, \& Levine, 1995; Wyatt, Katz, \& Kim, 2000) also shows that, next to family and close friends, work associates are the most likely group in which political communication takes place. Therefore, the workplace is a significant context for political socialization.

Another line of theorization, which the present study focuses on, investigates the potential effect of participatory work behavior (e.g., work decision making) on political participation. Pateman (1970) crystallizes the theoretical connection between workplace participation and a participatory democracy in what is generally known as the political spillover theory. According to Pateman, one's experience of participation in the workplace will influence his or her participation in a democratic political system outside the workplace. Participation is a learned behavior people acquire in their child- and adulthood. Political socialization of children in the family and in the school, although important, is inadequate (Almond \& Verba, 1965). Adult experiences are crucial. Because ordinary adults spend a great deal of their time at work, the workplace functions as a training ground for them. Based on Cole's (1918) argument that "a servile system industry inevitably reflects itself in political servility" (p. 35; also cited in Pateman, p. 38), Pateman contends:

Only if the individual could become self-governing in the workplace, only if industry was organized on a participatory basis, could this training for servility be turned into training for democracy and the individual gain the familiarity with democratic procedures, and develop the necessary "democratic character" for an effective system of large-scale democracy. (p. 38)

Pateman's provocative proposition crosses the boundaries between organizational research and political science research and suggests a dynamic and mutual relationship between the two spheres. It challenges scholars to provide empirical evidence 
and to explain mechanisms underlying the connections of the two domains. Since then a considerable amount of research has been generated.

Extant research considers workplace participation as having two dimensions: job autonomy and decision involvement. Job autonomy refers to one's level of control in accomplishing one's own job on a daily basis (Peterson, 1992). Decision involvement refers to how much say one has in the decision-making process of a work organization. In the domain of politics outside the workplace, participation consists of such behaviors as community involvement, political voting, and participation in political party and campaign activities in a democratic political system (Greenberg, 1986; Greenberg et al., 1996; Milbraith \& Goel, 1971; Peterson, 1992; R. Sobel, 1993).

Since Pateman, two streams of empirical research have emerged. One stream of research focuses on the association between work participation and IPE, and findings have lent strong support to this relationship (Elden, 1981; Mason, 1982; Sheppard \& Herrick, 1972). IPE refers to the feeling that one has the ability to have an impact on the political process (Morrell, 2003; Pateman, 1970). For instance, Elden (1981) studies a workplace designed according to the self-managing principles. He finds that "having some power over one's work covaries with one's attitude toward taking up participatory opportunities” (p. 51). However, as Greenberg (1986) observes, in these studies, although the relationship between work participation and IPE is supported, the connection with actual political participation is assumed instead of empirically studied.

Another line of research examines the direct association between workplace and political participation (Burn \& Konrad, 1987; Greenberg, 1986; Lafferty, 1989; Sobel, 1993). For example, R. Sobel (1993) argues that there is a direct correlation between forms of work participation and participation in politics and the correlation is ordered according to formality. For instance, he argues, voting is correspondent to formal work authority (i.e., "the rightful ability to tell others what to do"), and the less formal kind of participation, like protest, is linked to job participation (i.e., "the autonomy within one's own work sphere"). Based on the National Election Study Pilot Data, a moderate correlation is found. However, such formality-based connections seem arbitrary and have no solid theoretical basis.

As we mentioned earlier, the connecting mechanism underlying the possible association between work and politics, as Pateman (1970) proposes, is the mediating factor of IPE. The first stream of research assumes this mediated association but has not brought it to empirical tests. According to Pateman, job autonomy and decision involvement at work are the most significant contributors to the development of an individual's IPE, which then positively influences political participation. Pateman argues, "The structure of authority at the workplace is probably the most significant - and salient - structure of that kind with which the average man finds himself in daily contact" (p. 294). Various structures of authority in different work organizations stipulate different levels of job autonomy and decision involvement. Higher levels of job autonomy and participation in decision making at work increase the sense of being able to control work and its environment, which translates into a sense of political effectiveness. Increased IPE then leads to increased political participation 
(Almond \& Verba, 1965). Research has rarely tested this indirect relationship with the exception of Greenberg et al. (1996), whose research offers initial evidence that supports this proposition. To further test this mediated association, we propose the following hypotheses:

H1: The degree of job autonomy is positively associated with the degree of political participation.

$\mathrm{H} 2$ : IPE mediates the positive association between job autonomy and political participation.

H3: The degree of decision involvement at work is positively associated with the degree of political participation.

H4: IPE mediates the positive association between decision involvement at work and political participation.

Although work authority structure is crucial in shaping people's sense of control and effectiveness, job autonomy and work decision involvement, we argue, only reflect an instrumental view of work, which is about accomplishing production goals, and omit a social dimension of workplace as a community. Organizational research has long shown that workplace is more than transforming labor into products and services (e.g., Pacanowsky \& O’Donnel-Trujillo, 1983; Lambert \& Hopkins, 1995). Workplace is also a social community where people may socialize, form interpersonal relations that are not specified in labor contracts and perform certain rites and rituals together (Martin, 2002). We suspect that participation in this social community of work has direct association with political involvement. In the following section, we will propose participation in work community as a third dimension of workplace participation in addition to job autonomy and work decision involvement and will explore its implication to the spillover theory.

\section{Work Community Participation}

We use work community to refer to the associations among organizational members based on social and emotional needs and common moral values formed outside the formal authority structure and legal labor contracts (Felkins, 2002). In contrast to the instrumental definition of workplace, work community resembles the "gemeinschaft" side of workplace (Tonnies, 1963). The existence of work community is demonstrated in the literature of social support (Ray, 1987), emotion (Fineman, 1996), and learning in organizations (Brown \& Duguid, 1991), to name a few.

Work community as a social dimension of work results from recursive cultural practices that form the narratives, social rules, and agreements as the foundations of a community (Felkins, 2002). Gatherings at work, such as celebration of successes, holidays, and birthdays, provide opportunities in which common values and identity emerge. Informal interactions among members create and sustain social rules. Participation in the community is motivated by providing service to the common good (Felkins).

In addition, work community also develops through the outreach efforts of organizations to local communities outside the workplace. Corporate community 
involvement (Brammer \& Millington, 2003) not only takes the form of donation, sponsorship, and investment but also involves corporate-sponsored employee participation in community services. In the activities of helping local communities, employees strengthen their bonding and obtain a stronger sense of membership within both the workplace and local communities they serve.

Hence, we propose participation in the social community of workplace as a third dimension of workplace participation in addition to job autonomy and decision involvement. Is participation in work community, besides the instrumental aspects of work, positively associated with political participation? We want to explore this question in this study. We have said that the premise of the original political spillover theory is that a significant part of adult socialization takes place at work and workplace provides a training ground for political participation. We argue that such training not only take place in the instrumental sense of work, such as work decision making, but also in the sense of socialization and community orientation. Workplace provides a crucial ground for adults to gain experiences of forming associations with others, addressing common concerns, and resolving community conflicts. As in other dimensions of workplace participation, we suspect IPE may play a mediational role in the association between work community participation and political participation. Therefore, we propose the following hypotheses:

H5: The degree of work community participation is positively associated with the degree of political participation.

H6: IPE mediates the positive association between work community participation and political participation.

\section{Methods}

In the fall of 2004, a team of interviewers under the supervision of the authors, using a CATI (computer-aided telephone interviewing) system, conducted a regional telephone survey in a Midwest metropolitan area of the United States for a period of two weeks. Question items for this study constituted part of this survey. In this section, we will discuss the sample and survey instruments.

\section{Sample}

A total of 7,278 telephone numbers were randomly drawn through random-digit dialing. The study resulted in 281 completed surveys. By using the Outcome Rate Calculator (Version 2.1) based on the American Association for Public Opinion Research's (AAPOR) Standard Definitions (2006), the response rate (RR3) was $10.8 \%$, cooperation rate (COOP1) $21.2 \%$, and contact rate (CON2) $50.9 \%$. The low-response rate was partially due to the fact that the research project was conducted toward the end of the 2004 presidential campaign season in one of "the battleground states." The unprecedented campaign efforts by both parties may have generated significant fatigue among the population.

Because the survey items for this study required that participants were or had been employed in organizations by the time of the study, 115 surveys $(40.9 \%)$ out of 281 
were usable for this analysis. Among the participants, $38.3 \%$ were males $(N=44)$, $61.7 \%$ females $(N=71), 66.1 \%$ Caucasians $(N=76), 22.6 \%$ African Americans $(N=26)$, and $3.5 \%$ Hispanics $(N=4)$. The median household income was $\$ 43,571$ with modal income level between $\$ 50,001$ and $\$ 75,000$ (22.6\%). Participants who had some form of higher education accounted for $81.8 \%$ of the sample $(N=94)$. In comparison, the Year 2000 U.S. Census of this area reported $47.2 \%$ males, $52.8 \%$ females, $67.4 \%$ Whites, $27.4 \%$ African Americans, 3.4\% Hispanics, and $51.7 \%$ of the population with some form of higher education. The Census showed that the employed made up $58.6 \%$ of the population (including both "in labor force" and "not in labor force") and that the median household income was $\$ 39,168$ with modal income level between $\$ 50,000$ and $\$ 74,999$ (18.4\%). This comparison with the Census data indicates that females and people with higher income and higher education were overrepresented in the sample. Our inclusion criterion, which required participants to have "current or past employment" experience, may have contributed to oversampling people with higher education and higher income. The fact that the interview sessions started in late afternoon (5:30 p.m.) instead of early evening (e.g., 6:30 p.m.) may have contributed to oversampling females and undersampling the employed.

\section{Survey Instruments}

Based on our earlier discussion, workplace participation was measured along three dimensions. For each item of these three dimensions, participants reported on an 11 -point scale $(0=$ completely disagree, $5=$ neutral, and $10=$ completely agree $)$. An average score of the items for each dimension was calculated as its composite measure. The first dimension, Job Autonomy $(M=6.4, S D=2.25, \quad N=109$, $\alpha=.85$ ), consists of six items that were adopted from Seashore, Lawler, Mirvis, and Cammann (1983). The items examine the degree of control one has over one's individual job. For instance, "I have control in setting the pace of my work." The second dimension, Decision Involvement $(M=4.53, S D=2.88, N=111, \alpha=.80)$, is comprised of two items. One item measures decision involvement at the organizational level and the other at the work unit level. For instance, "In my work organization, decisions are often made by the top management without employees' input." The third dimension, Work Community Participation $(M=5.59, S D=2.71$, $N=112, \alpha=.71$ ), is comprised of three items. To reflect our conceptualization of this construct that we discussed earlier, the items measure the level of association with coworkers, participation in social events at work, and involvement in community services sponsored by the work organization. An example is, "I often attend social events organized by coworkers, such as holiday parties or baby showers."

Based on the existing literature (Greenberg et al., 1996; Milbraith \& Goel, 1971; Peterson, 1992; R. Sobel, 1993), we define political participation as consisting of three types of activities: participation in community affairs, participation in political voting, and participation in political party and campaign activities. As a result, three 
political participation variables were measured with items adopted from Milbraith and Goel (1971) and R. Sobel (1993). Participants responded to each question by "yes," "no," or "don't remember," ( $1=$ yes, $0=$ no, missing information = don't remember). For each of the three variables, a composite measure was calculated by averaging the scores of the respective variable items. First, Participation in Community $(M=.42, S D=.44, N=115, \varphi=.59, p<.001)$ consists of two items that examine the level of involvement in local problems and issues. A sample item is "Worked with others in your community to solve some community problems." Second, Participation in Voting $(M=.74, S D=.39, N=115, \varphi=.60, p<.001)$ has two items, "Voted in the 2000 election" and "voted in the [State] primary election earlier this year." Third, Participation in Political Party and Campaigning $(M=.36, S D=.36, N=114, K R 20=.62)$ has three items, for example, "worn a button or put a sticker on your car."

The measurement of IPE consists of four items $(M=6.54, S D=2.02, N=114$, $\alpha=.76$ ), which were adopted from Niemi, Craig, and Mattei (1991). For instance, "I think that I am better informed about politics and government than most people." Participants reported on an 11-point scale $(0=$ completely disagree, $5=$ neutral, and $10=$ completely agree). An average score of the four items was calculated as its composite measure.

\section{Data Analysis}

We used SPSS 11.0 to analyze the statistical data. Correlational analyses were first conducted. Because prior research indicated that such background variables as age, education, and income level are significant predictors of political participation (Brady, Verba, \& Schlozman, 1995), we conducted both zero-order correlational analysis and partial correlational analysis controlling for the effects of these background variables.

To conduct mediation analyses, we followed the four logical conditions for establishing mediation as outlined by Baron and Kenny (1986) (see also Kenny, Kashy, \& Bolger, 1998, pp. 258-260). These conditions are to (1) demonstrate that the independent variable is correlated with the outcome variable prior to the introduction of the mediator; (2) demonstrate that the independent variable is correlated with the mediator; (3) demonstrate that the mediator is correlated with the outcome variable while controlling for the effect of the independent variable; and (4) demonstrate that, controlling for the mediator, the effect of the independent variable on the outcome variable is zero. If all four conditions are met, the hypothesis of complete mediation is supported. If the first three conditions are met but the fourth one is not, then partial mediation is indicated. It is simple mediation if only conditions (2) and (3) are met.

Three sets of multiple regression analyses were conducted to test these conditions. The first set of multiple regression models was used to test the first condition regarding the effects of variables of workplace participation on each of the three variables of political participation without introducing IPE as the mediator. This set of tests offered results for $\mathrm{H} 1, \mathrm{H} 3$, and $\mathrm{H} 5$, which predict direct positive association between 
variables of workplace participation and political participation. The second set tested the second condition - the effects of variables of workplace participation on the mediator. The final set of models assessed the third and fourth condition in which the mediator was introduced. In all the regression models, age, education, and income were first entered as control variables.

To directly assess the mediation effect as predicted by $\mathrm{H} 2, \mathrm{H} 4$, and $\mathrm{H} 6$, we employed MacKinnon, Lockwood, and Hoffman (1998) distribution of products test. Based on MacKinnon, Lockwood, Hoffman, West, and Sheets (2002), Holbert and Stephenson (2003) recommend the use of this test when researchers work with a small sample size (less than 200). Comparing with the more widely used Sobel test (1982), Preacher and Hayes (2008) confirm that the distribution of products method performs better when the sample size of a study is small.

\section{Results}

Tables 1 and 2 summarize results from correlation analyses and the first set of multiple regression models respectively. Table 3 combines results from the second and third set of regression models that involve IPE. H1 predicts that job autonomy is positively associated with political participation and $\mathrm{H} 2$ holds that IPE mediates this relationship. Regression analyses reveal no significant direct effect of job autonomy on political participation and, hence, do not support H1. Instead, results show that job autonomy is a significant predictor of IPE $(\beta=.31, p=.003)$, which, then, significantly predicts the level of political participation in community $(\beta=.21$, $p=.04)$, voting $(\beta=.23, p=.02)$, and political party and campaign $(\beta=.22$, $p=.03$ ). The fact that conditions (2) and (3) for establishing mediation are met suggests simple mediation by IPE (Kenny, Kashy, \& Bolger, 1998). MacKinnon et al. (1998) mediation test confirms the significant mediating effect by IPE between job autonomy and each of the three factors of political participation: community $(P=6.32, p<.05$, standardized specific indirect effect $=.07)$, political party and campaign $(P=7.16, p<.05$, standardized specific indirect effect $=.07)$, and voting

Table 1 Correlation Matrix (Pearson's Correlation Coefficient, $r$ )

\begin{tabular}{|c|c|c|c|c|c|c|}
\hline Variables & 2 & 3 & 4 & 5 & 6 & 7 (IPE) \\
\hline 1. Community & $.13(.07)$ & $.35^{* * *}\left(.31^{* *}\right)$ & $.05(.01)$ & $.27^{* *}\left(.21^{*}\right)$ & $.15(.14)$ & $.25^{* *}\left(.21^{*}\right)$ \\
\hline 2. Voting & & $.19^{*}\left(.18^{*}\right)$ & $.16^{*}(.13)$ & $-.01(-.05)$ & $.19^{*}\left(.23^{*}\right)$ & $.26^{* *}\left(.26^{* *}\right)$ \\
\hline 3. Party and campaign & & & $.13(.11)$ & $.27^{* *}\left(.23^{*}\right)$ & $.08(.06)$ & $.28^{* *}\left(.25^{* *}\right)$ \\
\hline 4. Job autonomy & & & & $.23^{* *}\left(.21^{*}\right)$ & $.18^{*}\left(.19^{*}\right)$ & $.33^{* * *}\left(.32^{* *}\right)$ \\
\hline 5. Work community & & & & & $.12(.10)$ & $.18^{*}(.14)$ \\
\hline 6. Decision involvement & & & & & & $.00(-.02)$ \\
\hline
\end{tabular}

Note. Cell entries are zero-order correlations; numbers in parentheses are partial correlations, controlling for age, education, and income.

${ }^{*} p<.05$ (1-tailed), ${ }^{* *} p<.01$ (1-tailed), ${ }^{* * *} p<.001$ (1-tailed). 
Table 2 Summary of Regression Analyses without IPE (Mediator)

\begin{tabular}{llll}
\hline Variables & Community participation & Voting & Political party and campaign \\
\hline Controls & & & \\
$\quad$ Age & $.10(.03)$ & $.29^{* *}(.02)$ & $-.02(.02)$ \\
$\quad$ Education & $.22^{*}(.04)$ & $.09(.04)$ & $.16(.04)$ \\
$\quad$ Income & $.07(.02)$ & $.11(.02)$ & $-.02(.02)$ \\
Workplace participation & & & $.07(.02)$ \\
$\quad$ Job autonomy & $-.05(.02)$ & $.11(.02)$ & $.20^{*}(.01)$ \\
$\quad$ Work community & $.21^{*}(.02)$ & $.06(.01)$ & $.04(.01)$ \\
$\quad$ Decision involvement & $.13(.02)$ & $.19^{* a}(.01)$ & $.05^{*}$ \\
Adjusted $R$ square & $.11^{*}$ & $.10^{*}$ & \\
\hline
\end{tabular}

Note. Cell entries are standardized coefficients and entries in parentheses are standard errors.

${ }^{*} p<.05,{ }^{* *} p<.01,{ }^{* * *} p<.001$.

${ }^{a} p=.057$.

$(P=6.87, p<.05$, standardized specific indirect effect $=.07)$. Therefore, $\mathrm{H} 2$ is supported.

H3 holds that decision involvement is positively associated with political participation and H4 predicts that IPE mediates this relationship. Correlational analysis shows a significant direct association between decision involvement and political voting $(r=.23, p=.01)$, controlling for the effects of background variables. Supporting $\mathrm{H} 3$, regression analyses reveal a significant direct effect of decision involvement on political voting $(\beta=.20, p=.04)$, controlling for the effects of other independent

Table 3 Summary of Regression Analyses with IPE (Mediator)

\begin{tabular}{|c|c|c|c|c|}
\hline Variables & $\begin{array}{l}\text { Community } \\
\text { participation }\end{array}$ & Voting & $\begin{array}{l}\text { Political party and } \\
\text { campaign }\end{array}$ & IPE \\
\hline \multicolumn{5}{|l|}{ Controls } \\
\hline Age & $.10(.03)$ & $.31^{* *}(.02)$ & $-.02(.02)$ & $-.08(.12)$ \\
\hline Education & $.19(.04)$ & $.07(.04)$ & $.12(.04)$ & $.12(.20)$ \\
\hline Income & $.05(.02)$ & $.11(.02)$ & $-.04(.02)$ & $.01(.10)$ \\
\hline \multicolumn{5}{|l|}{ Workplace participation } \\
\hline Job autonomy & $-.12(.02)$ & $.04(.02)$ & $-.01(.02)$ & $.31^{* *}(.09)$ \\
\hline Work community & $.20^{*}(.02)$ & $-.08(.01)$ & $.20^{*}(.01)$ & $.07(.08)$ \\
\hline Decision involvement & $.13(.02)$ & $.20^{*}(.01)$ & $.04(.01)$ & $-.07(.07)$ \\
\hline IPE & $.21^{*}(.02)$ & $.23^{*}(.02)$ & $.22^{*}(.02)$ & - \\
\hline Adjusted $R$ square & $.12^{*}$ & $.14^{*}$ & $.08^{*}$ & $.08^{*}$ \\
\hline
\end{tabular}

Note. Cell entries are standardized coefficients and entries in parentheses are standard errors. ${ }^{*} p<.05,{ }^{* *} p<.01,{ }^{* * *} p<.001$. 
variables and background variables. However, decision involvement does not demonstrate any direct effect on the mediator. Hence, the second condition for mediation is not met. In line with this result, MacKinnon et al. (1998) mediation test does not reveal any significant mediation effect by IPE. Therefore, H4 is not supported.

$\mathrm{H} 5$ predicts a positive association between participation in work communities and in politics, and H6 states that IPE mediates this relationship. Controlling for background variables, the degree of work community participation is significantly correlated with participation in local communities $(r=.21, p=.019)$ and political party and campaign activities $(r=.23, p=.01)$. Based on the regression analyses, work community participation significantly predicts the level of involvement in local communities $(\beta=.20, p=.04)$ and participation in political party and campaign activities $(\beta=.20, p=.05)$, controlling for the effects of background variables, job autonomy, decision involvement, and IPE. MacKinnon et al. (1998) mediation test confirms that no mediation effect by IPE exists. Hence, the results support H5 regarding the direct positive association between work community participation and political participation but show no support for H6. In the following section, we will interpret these results and discuss their implications. We will also address the study's limitations and directions for future research.

\section{Discussion}

Brady, Verba, and Schlozman (1995) propose, "Both the motivation and the capacity to take part in politics have their roots in the fundamental non-political institutions with which individuals are associated during the course of their lives (p. 3; also cited in Edwards \& Foley, 1998). Among many forms of nonpolitical institutions the workplace is the focus of our study. Specifically, we are interested in examining the association between workplace participation and political involvement.

Based on the statistical results, we can draw several conclusions. First, the present study provides partial support to the political spillover theory (Pateman, 1970). The theory suggests that both job autonomy and decision involvement at work are associated with political participation via the mediation of IPE. Our study shows that this mediation effect only applies to job autonomy not decision involvement. A higher level of control an employee has over his or her immediate job is associated with a stronger sense of personal political effectiveness (Elden, 1981; Mason, 1982; Sheppard \& Herrick, 1972), which, in turn, is associated with a higher level of participation in local communities, voting, and political party and campaign activities.

Second, unlike what the political spillover theory predicts, our study reveals that the association between decision involvement at work and political participation (voting) is direct. In other words, employees who are given more opportunities to make work-related decisions tend to participate more in political voting. Then, what mechanism enables this relationship if not mediated by IPE? We speculate that decision involvement cultivates certain communication patterns that spillover workplace boundaries. Communication patterns as a spillover mechanism have found support in studies of work effects on family communication. Ritchie (1997) reveals 
that communication patterns of parents at work influence patterns of family communication. For instance, parents who experience open communication at work tend to encourage unconstrained communication in family (Ritchie, 1997). It is possible that participation in decision making at work cultivates a pattern or habit of involvement in collective events. Political voting certainly resembles decision-making behavior at work. In addition, being involved in decision making may forge a sense of moral obligation and imperative (Etzioni, 1988) toward a collective to which one belongs. It is a sense that 'they 'must' behave in the prescribed way, that they are in fact obligated, duty bound" (Etzioni, p. 42). Instead of being a mediating factor like IPE, this sense of moral obligation is a decision-making premise (Tompkins \& Cheney, 1985) that transcends the boundaries between work and politics. Whether it is communication patterns or moral obligation, or both, that link decision involvement in the two realms demands future empirical research.

Thirdly, the results offer strong support to the direct association between participation in work community and involvement in politics. Expanding the traditional definition of workplace participation, work community (Felkins, 2002) acknowledges the importance of workplace as a ground for association and socialization that goes beyond formal authority relations as stipulated in labor contracts. The finding of its association with political involvement resonates with findings in other studies that intend to uncover the political impact of workplace as a social context. For example, employee participation in work communities creates opportunities for them to be exposed to cross-cutting political conversations (Mutz \& Mondak, 2006) and to form important social networks that constitute social capital (Coleman, 1990; Putnam, 2000).

In addition to the above theoretical findings, this study carries practical implications for both organizational and political communication. The pressures of time and money, suburbanization, electronic entertainment, and generational change have been argued to contribute to the often-lamented political apathy (Putnam, 2000). This study provides empirical support for another source: practices at work. First, the findings imply that displacement and disruption of work communities destroy workplace as a fertile ground for cultivating patterns and norms of social connection and political socialization. Organizational research demonstrates that organizational practices, such as reengineering, downsizing, and outsourcing, motivated by an overemphasis on financial profitability, destabilize informal organizational networks (Fisher \& White, 2000; Freeman \& Cameron, 1993; Heckscher, 1995; Keller, 1989) and local communities (Deetz, 1995) and discourage the formation of communityoriented values (Ezzy, 2001). Second, employees who are deprived of decision-making opportunities at work lose the training ground for cultivating communication patterns and the moral imperative oriented toward the public good. Earlier research has provided ample support to the positive effects of decision involvement at work on employees both cognitively (Monge \& Miller, 1988) and attitudinally (Marshall \& Stohl, 1993) in relation to an organization. The findings of this study suggest that the positive outcomes of decision involvement extend beyond the organizational boundaries into the public sphere. 
The study has several limitations. First, the survey results from this study only provide us with correlational results, instead of causal relationships, between workplace participation and political involvement. Especially, interpretation of the relationship between work community and political participation should be cautious. Unlike job autonomy and decision involvement, which are conceptualized and measured as involuntary organizational arrangements, work community participation consists of voluntary actions. This study was not able to control for or rule out other variables, such as the gregarious personality trait, which may underlie the association between work community participation and political involvement. Second, the findings are limited by a low-response rate. A higher response rate in the future would certainly increase the generalizability of the results. Third, the results are based on participants' self-report, which is subject to such validity threats as inaccurate information recall and social desirability bias among others. Other methods, such as case studies, can be employed in the future to test and to advance the theory. Fourth, the cross-sectional design of the study only provides a snapshot of the association between workplace participation and political participation. Future research can explore how changes in workplace participation over time are associated with any changes in political involvement.

Overall, our study suggests that the boundaries between work, local community, and the political arena are permeable. Lack of participatory work practices may fuel political apathy and undermine democratic political processes. As a result, the findings challenge the traditional separation of the private and pubic sphere (Habermas, 1992), which grants workplace a private status and shields it from democratic standards (Brenkert, 1992). Our findings provide empirical evidence for Deetz's (1992) argument, "corporations are the new public sphere," (p. 348) by showing that everyday practices at work, such as decision making and job control, may have significant impact on the public sphere. We hope that this study could prompt critical reflections on our work practices and help ignite positive changes in both work and politics.

\section{References}

Almond, G. \& Verba, S. (1965). The civic culture. Boston, MA: Little Brown \& Co.

American Association for Public Opinion Research. (2006). Standard definitions: Final dispositions of case codes \& outcome rates for surveys (4th ed.). Lenexa, KS: Author.

Baron, R. M. \& Kenny, D. A. (1986). The moderator-mediator variable distinction in social psychological research: Conceptual, strategic, and statistical considerations. Journal of Personality and Social Psychology, 51(6), 1173-1182.

Brady, H. E., Verba, S., \& Schlozman, K. L. (1995). Beyond SES: A resource model of political participation. The American Political Science Review, 89, 271-294.

Brammer, S. \& Millington, A. (2003). The effect of stakeholder preferences, organizational structure and industry type on corporate community involvement. Journal of Business Ethics, 45, 213-226.

Brenkert, G. G. (1992). Freedom, participation, and corporations: The issue of corporate (economic) democracy. Business Ethics Quarterly, 2(3), 251-269.

Brown, J. \& Duguid, P. (1991). Organizational learning and communities-of-practice: Toward a unified view of working, learning, and innovation. Organization Science, 2, 40-57. 
Burn, S. M. \& Konrad, A. M. (1987). Political participation: A matter of community, stress, job autonomy, and contact by political organizations. Political Psychology, 8, 125-138.

Cassel, C. A. (1999). Voluntary associations, churches, and social participation: Theories of turnout. Social Science Quarterly, 80, 504-517.

Cheney, G. (1995). Democracy in the workplace: Theory and practice from the perspective of communication. Journal of Applied Communication Research, 23, 167-200.

Cheney, G., Straub, J., Speirs-Glebe, L., Stohl, C., Degooyer, D., Jr., Whalen, S., Garvin-Doxas, K., \& Carlone, D. (1998). Democracy, participation, and communication at work: A multidisciplinary review. In M. E. Roloff (Ed.), Communication yearbook: Vol. 12 (pp. 35-92). Thousand Oaks, CA: Sage.

Cole, G. (1918). Labor in the commonwealth. London: Headley Bros.

Cole, G. (1919). Self-government in industry. London: G. Bell \& Sons.

Coleman, J. S. (1990). Foundations of social theory. Cambridge, MA: Harvard University Press.

Dahl, R. (1956). Preface to democratic theory. Chicago, IL: University of Chicago Press.

Deetz, S. (1992). Democracy in an age of corporate colonization: Developments in communication and the politics of everyday life. Albany, NY: SUNY Press.

Deetz, S. (1995). Transforming communication, transforming business: Building responsive and responsible workplaces. Cresskill, NJ: Hampton Press.

Edwards, B. \& Foley, M. W. (1998). Civil society and social capital beyond Putnam. American Behavioral Scientist, 42, 124-140.

Elden, J. M. (1981). Political efficacy at work: The connection between more autonomous forms of workplace organization and a more participatory politics. The American Political Science Review, 75(1), 43-58.

Etzioni, A. (1988). The moral dimension: Towards a new economics. New York: Collier Macmillan.

Ezzy, D. (2001). A simulacrum of workplace community: Individualism and engineered culture. Sociology, 35(3), 631-650.

Felkins, P. K. (2002). Community at work: Creating and celebrating community in organizational life. Cresskill, NJ: Hampton Press, Inc.

Fineman, S. (1996). Emotion and organizing. In S. Clegg, C. Hardy, \& W. Nord (Eds.), Handbook of organization studies (pp. 543-564). Thousand Oaks, CA: Sage.

Fisher, S. R. \& White, M. A. (2000). Downsizing in a learning organization: Are there hidden costs. Academy of Management Review, 25(1), 244-251.

Freeman, S. J. \& Cameron, K. S. (1993). Organizational downsizing: A convergence and reorientation framework. Organization Science, 4, 10-28.

Greenberg, E. (1986). Workplace democracy: The political effects of participation. Ithaca, NY: Cornell University Press.

Greenberg, E. S., Grunberg, L., \& Daniel, K. (1996). Industrial work and political participation: Beyond "simple spillover." Political Research Quarterly, 49, 305-330.

Habermas, J. (1992). Further reflections on the public sphere. In C. Calhoun (Ed.), Habermas and the public sphere (pp. 421-461). Cambridge, MA: The MIT Press.

Harrison, T. (1994). Communication and interdependence in democratic organizations. In S. Deetz (Ed.), Communication yearbook: Vol. 17 (pp. 247-274). Newbury Park, CA: Sage.

Heckscher, C. (1995). White-collar blues: Management loyalties in an age of corporate restructuring. New York: Basic Books.

Holbert, R. L. \& Stephenson, M. T. (2003). The importance of indirect effects in media effects research: Testing for mediation in structural equation modeling. Journal of Broadcasting \& Electronic Media, 47, 556-572.

Huckfeldt, R., Beck, P. A., Dalton, R. J., \& Levine, J. (1995). Political environments, cohesive social groups, and the communication of public opinion. American Journal of Political Science, 39(4), 1025-1054.

Keller, M. (1989). Rude awakening: The rise, fall, and struggle for the recovery of general motors. New York: William Morrow. 
Kenny, D. A., Kashy, D. A., \& Bolger, N. (1998). Data analysis in social psychology. In D. T. Gilbert, S. T. Fiske, \& G. Lindzey (Eds.), The handbook of social psychology (4th ed., pp. 233-265). Boston, MA: The McGraw-Hill Companies, Inc.

Kwak, N., Shah, D. V., \& Holbert, R. L. (2004). Connecting, trusting, and participating: The direct and interactive effects of social associations. Political Research Quarterly, 57(4), 643-652.

Lafferty, W. (1989). Work as a source of political learning among wage-laborers and lower-level employees. In R. S. Sigel (Ed.), Political learning in adulthood (pp. 102-142). Chicago, IL: University of Chicago Press.

Lambert, S. J. \& Hopkins, K. (1995). Occupational conditions and workers' sense of community: Variations by gender and race. American Journal of Community Psychology, 23, 151-180.

MacKinnon, D. P., Lockwood, C. M., \& Hoffman, J. M. (1998). A new method to test for mediation. Paper presented at the annual meeting of the Society for Prevention Research, Park City, UT.

MacKinnon, D. P., Lockwood, C. M., Hoffman, J. M., West, S. G., \& Sheets, V. (2002). A comparison of methods to test mediation and other intervening variable effects. Psychological Methods, 7, 83-104.

Marshall, A. A. \& Stohl, C. (1993). Participating as participation: A network approach. Communication Monographs, 60, 137-157.

Martin, J. (2002). Organizational culture: Mapping the terrain. Thousand Oaks, CA: Sage.

Mason, R. (1982). Participatory and workplace democracy: A theoretical development in critique of liberalism. Carbondale, IL: Southern Illinois University Press.

McLagan, P. \& Nel, C. (1995). The age of participation: New governance for the workplace and the world. San Francisco, CA: Berrett-Koehler Publishers.

Milbraith, L. \& Goel, M. (1971). Political participation (2nd ed.). Chicago: Rand McNally.

Mill, J. S. (1910). Representative government. London: Oxford University Press.

Mondak, J. J. \& Mutz, D. C. (2001). Involuntary association: How the workplace contributes to American civic life. Presented at the Annual Meeting of the Midwest Political Science Association.

Monge, P. R. \& Miller, K. I. (1988). Participative processes in organizations. In G. M. Goldhaber \& G. A. Barnett (Eds.), Handbook of organizational communication (pp. 213-229). Norwood, NJ: Ablex.

Morrell, M. E. (2003). Survey and experimental evidence for a reliable and valid measure of internal political efficacy. Public Opinion Quarterly, 67, 589-602.

Mutz, D. C. \& Mondak, J. J. (2006). The workplace as a context for cross-cutting political discourse. The Journal of Politics, 68(1), 140-155.

Niemi, R. G., Craig, S. C., \& Mattei, F. (1991). Measuring internal political efficacy in the 1988 National Election Study. American Political Science Review, 85, 1407-1413.

Pacanowsky, M. \& O’Donnel-Trujillo, N. (1983). Organizational communication as cultural performance. Communication Monographs, 50, 126-147.

Pateman, C. (1970). Participation and democratic theory. London: Cambridge University Press.

Peterson, S. (1992). Workplace politicization and its political spillovers: A research note. Economic and Industrial Democracy, 13, 511-524.

Preacher, K. J. \& Hayes, A. F. (2008). Contemporary approaches to assessing meditation in communication research. In A. Hayes, M. Slater, \& L. Snyder (Eds.), The Sage sourcebook of advanced data analysis methods for communication research. Thousand Oaks, CA: Sage.

Putnam, R. (1995). Bowling alone: America's declining social capital. Journal of Democracy, 6, 65-78.

Putnam, R. (2000). Bowling alone: The collapse and revival of American community. New York: Simon \& Schuster.

Ray, E. B. (1987). Supportive relationship and occupational stress in the workplace. In T. L. Albrecht \& M. B. Adelman (Eds.), Communicating social support (pp. 172-191). Beverly Hills, CA: Sage. 
Ritchie, L. D. (1997). Parents' workplace experiences and family communication patterns. Communication Research, 24, 175-187.

Rousseau, J. J. (1968). The social contract (M. Cranston, Trans.). London: Penguin Books.

Seashore, S., Lawler, E., III, Mirvis, P., \& Cammann, C. (1983). Assessing organizational change. New York: Wiley.

Seibold, D. \& Shea, B. C. (2001). Participation and decision making. In F. Jablin \& L. Putnam (Eds.), The new handbook of organizational communication: Advances in theory, research, and methods (pp. 664-703). Thousand Oaks, CA: Sage.

Sheppard, H. L. \& Herrick, N. Q. (1972). Where have all the robots gone? New York: Free Press.

Sobel, M. E. (1982). Asymptotic intervals for indirect effects in structural equations model. In S. Leinhart (Ed.), Sociological methodology 1982 (pp. 290-312). San Francisco: Jossey-Bass.

Sobel, R. (1993). From occupational involvement to political participation: An exploratory analysis. Political Behavior, 15, 339-353.

Stohl, C. \& Cheney, G. (2001). Participatory processes/paradoxical practices: Communication and the dilemmas of organizational democracy. Management Communication Quarterly, 14, 349-407.

Tompkins, P. K. \& Cheney, G. (1985). Communication and unobtrusive control in contemporary organizations. In R. D. McPhee \& P. K. Tompkins (Eds.), Organizational communication: Traditional themes and new directions (pp. 179-210). Beverly Hills, CA: Sage.

Tonnies, F. (1963). Communities and society (C. Loomis, Trans.). New York: Harper Torchbook.

Wyatt, R. O., Katz, E., \& Kim, J. (2000). Bridging the spheres: Political and personal conversation in public and private spaces. Journal of Communication, 50, 71-92. 